Western North American Naturalist 69(4), ( 2009, pp. 501-510

\title{
POPULATION ECOLOGY AND REPRODUCTION OF THE MEXICAN MUD TURTLE (KINOSTERNON INTEGRUM) IN TONATICO, ESTADO DE MÉXICO
}

\author{
Rodrigo Macip-Ríos ${ }^{1,4}$, Maria de Lourdes Arias Cisneros ${ }^{2}$, Xochitl S. \\ Aguilar-Miguel $^{3}$, and Gustavo Casas-Andreu ${ }^{1}$
}

\begin{abstract}
Ecological data directly from the field are important in understanding the life history strategies of kinosternid species in the tropics. Herein we summarize the basic population ecology and life history of Kinosternon integrum in the municipality of Tonatico (southeastern Estado de México, México). From October 2003 to November 2004, we marked a total of 204 turtles and recaptured 118 of them. Mean population size using the Jolly-Seber model was 197 (95\% CI 128-416) individuals, with a sex ratio of 1:1.7, biased to females. Males were larger than females in carapace length and plastron length. The reproductive season starts in late June and finishes in late October. The smallest female with oviductal eggs was $122 \mathrm{~mm}$ in carapace length. Mean clutch size was 4 eggs $(s=1.77$, range $1-8)$ and was significantly and positively related to body size. Mean egg length was $30.43 \mathrm{~mm}(s=2.24$, range 23.92-35.96), mean width was $16.35 \mathrm{~mm}(s=1.01$, range 12.99-18.30), and mean weight was $5.14 \mathrm{~g}(s=0.60$, range 3.41-6.57). Mean egg length was significantly and inversely related to clutch size. Relative clutch mass (reproductive effort) was $0.043(s=0.017$, range $0.017-0.071$ ), which is the smallest value reported for the genus Kinosternon. Additionally, there was no evidence of a pelvic restriction on egg size in this population. This is the first study that documents basic population ecology and reproductive characteristics for a single population of the most widespread freshwater turtle in Mexico.
\end{abstract}

Key words: clutch size, Kinosternon integrum, population size, reproductive effort, sex ratio.

Kinosternids are a highly diverse group of turtles in México (Pritchard and Trebbau 1984) with 18 species distributed throughout the country (Liner and Casas-Andreu 2008). Kinosternon integrum has the most widespread distribution in the country, and its sister species, $K$. scorpioides, is widespread in northern and central South America (Iverson 1999). Kinosternon integrum is endemic to central and western México, where it inhabits diverse habitats over an altitudinal range between sea level and 2300 $\mathrm{m}$ (Iverson et al. 1998). The key to the success of this group in the Mexican tropics remains unknown, but special adaptations such as aestivation behavior, a "bet-hedging" life history strategy, and an omnivorous diet (Aguirre-León and Aquino-Cruz 2004, Macip-Rios unpublished data) could be important factors.

Demographic and life history studies on $K$. integrum are limited. Life tables have been constructed for congeneric species such as $K$. flavescens (Iverson 1991a) and K. subrubrum (Frazer 1991), and some information is also available on sex ratios (Carr and Mast 1988, Edmonds and Brooks 1996, Smith and Iverson 2002) and population sizes (Gibbons 1983, Moll 1990) of several North American species. For Mexican kinosternids, there are studies on the natural history of $K$. chimalhuaca (Berry et al. 1997), K. oaxacae (Iverson 1986), and K. alamosae (Iverson 1989), but the information on $K$. integrum is limited and anecdotal.

Iverson (1999) described the general reproductive pattern of $K$. integrum based on data from several localities within this species' range, but no information is available on its demography or on basic trends in its population ecology. The aim of this paper is to describe basic trends in population ecology and life history (including possible pelvic restriction on egg size) for a natural population of $K$. integrum in Tonatico, Estado de México, in the upper Río Balsas basin, México. Our paper is the first to present such information on $K$. integrum, which is a representative species of the kinosternid turtle group in the Mexican dry tropic.

\footnotetext{
${ }^{1}$ Instituto de Biología, Universidad Nacional Autónoma de México. Circuito exterior S/N, Ciudad Universitaria, Coyoacán, Distrito Federal, México. C.P. 04510.

${ }^{2}$ Departamento de Pequeñas Especies, Facultad de Verterinaria y Zootécnia, Universidad Nacional Autónama de México. Circuito exterior S/N, Ciudad Universitaria, Coyoacán, Distrito Federal, México. C.P. 04510.

${ }^{3}$ Centro de Investigación en Recursos Bióticos, Instituto Literario No. 100, Col. Centro, Toluca, Estado de México, C.P. 50000.

4E-mail: rmr@ibiologia.unam.mx
} 


\section{Methods}

We conducted this study from October 2003 to November 2004 in the vicinity of Tonatico, Estado de México $\left(18^{\circ} 48^{\prime} \mathrm{N}, 99^{\circ} 40^{\prime} \mathrm{W}\right)$. Tonatico is located in southeastern Estado de México, in the northern portion of the Río Balsas basin, at $1640 \mathrm{~m}$ above sea level. Vegetation is a mixture of tropical dry deciduous forest, agricultural (corn) fields, and cattle-breeding lands, combined with seasonal ponds that the turtles inhabit. The average monthly temperature is 20 ${ }^{\circ} \mathrm{C}$ and the average monthly rainfall is $150 \mathrm{~mm}$, with a maximum monthly rainfall of $401.5 \mathrm{~mm}$ in the rainy season (June-October) and a maximum monthly rainfall of $30.3 \mathrm{~mm}$ in the dry season (November-May) (INEGI 2002).

Ponds where turtles were collected were circular and shallow, ranging from 2 to $200 \mathrm{~m}$ in diameter and from 50 to $200 \mathrm{~cm}$ in water depth. We sampled 7 ponds of the following diameters: 200, 50, 20, 10, 8, 5, and $3 \mathrm{~m}$. The larger ponds $(200$ and $50 \mathrm{~m})$ were $4 \mathrm{~km}$ away from each other; the smaller ponds $(20,10,8$, 5 , and $3 \mathrm{~m}$ ) were approximately a $50 \mathrm{~m}$ away from each other, and this group of ponds was $200 \mathrm{~m}$ away from the 50-m-diameter pond. Turtles were also collected in a temporary stream near the 50-m pond. These ponds were very productive because cattle drink there and their fecal deposits cause eutrophication of the water. The typical faunal succession of seasonal lentic systems occurs in the ponds (Lampert and Sommer 1997), with invertebrates like dragonflies, beetles, and other insects being the most abundant prey for turtles. Other species common to this habitat include amphibians such as Hypopachus variolosus, Lithobates forreri, and Hyla arenicolor and reptiles such as semiaquatic snakes (Drymarchon melanurus).

We visited the study site monthly and caught turtles by seine and also by baited hoop traps. We seined 3 of the biggest ponds $(200,50$, and $20 \mathrm{~m}$ ) until no more turtles appeared in the net. On 2 nights, we set 10 traps (baited with fresh fish) in the other 4 ponds (4 traps in the 10-m-diameter pond and 2 in the 8-, 5-, and 3$\mathrm{m}$-diameter ponds). We performed the same capture effort on every visit to the study site for a total effort of 6 seine events per large pond and 10 traps per 2 nights each month on the small ponds. In the dry season, the larger ponds dry out; therefore, during this time, we focused on the small ponds that remained filled due to dense vegetation cover.

Turtles were marked (by notching marginal scutes [Ferner 1979]), measured, weighed, and released. For each turtle, we measured carapace length (CL), plastron length (PL), carapace width $(\mathrm{CW})$, plastron width $(\mathrm{PW})$, carapace height $(\mathrm{CH})$, and body mass (BM). Sex was determined by a single secondary sexual character-the conspicuous, long tail in adult males. Females that had a plastron length larger than $110 \mathrm{~mm}$ were brought to the laboratory and $\mathrm{X}$ rayed to determine if they were gravid, and if so, clutch size was recorded (Gibbons and Greene 1979). Eggs were collected from gravid females by injecting an oxitocin dose at a concentration of $1.5 \mathrm{~mL} \cdot \mathrm{kg}^{-1}$ (Ewert and Legler 1978). Turtles were then placed in $30 \mathrm{~mm}$ of water in a plastic box until the eggs were released. We measured egg length and width with a dial caliper $( \pm 0.02 \mathrm{~mm})$ and egg mass with an analytical balance $( \pm 0.01 \mathrm{~g})$. All measurements were conducted by the same person each time. To avoid measurement bias, we did not weigh eggs that remained more than 5 minutes in the water. On the X-ray plates, we measured the pelvic opening and the egg width of each turtle with eggs in the oviduct in order to determine whether there was a pelvic restriction on egg size (Congdon and Gibbons 1987; see statistical procedures below).

We conducted a multiple regression analysis to examine the influence of average monthly temperatures and average monthly rainfall on turtle abundance throughout the year. For this test, we used climate data provided by the Centro Meteorológico Nacional-México for Ixtapan de la Sal municipality, which is located near Tonatico (approximately $12 \mathrm{~km}$ away). We used the Jolly-Seber model (Krebs Ecological Methodology, version 0.94 [software]; Krebs 1996, Krebs and Brzustowski 1998) to estimate population size. To test the hypothesis of a 1:1 sex ratio (Wilson and Hardy 2002), we used a standard chi-square test (Krebs 1996).

A multivariate Hotelling's $T^{2}$ test was conducted on the morphological data (CL, CW, PL, PW, and CH as input variables) to explore for significant sexual dimorphism in body size measurements (Rancher 2002). We compared body mass between males and females with the nonparametric Wilcoxon's 2-sample test, as the body mass variable was not normally distributed. Reproductive effort was estimated by 


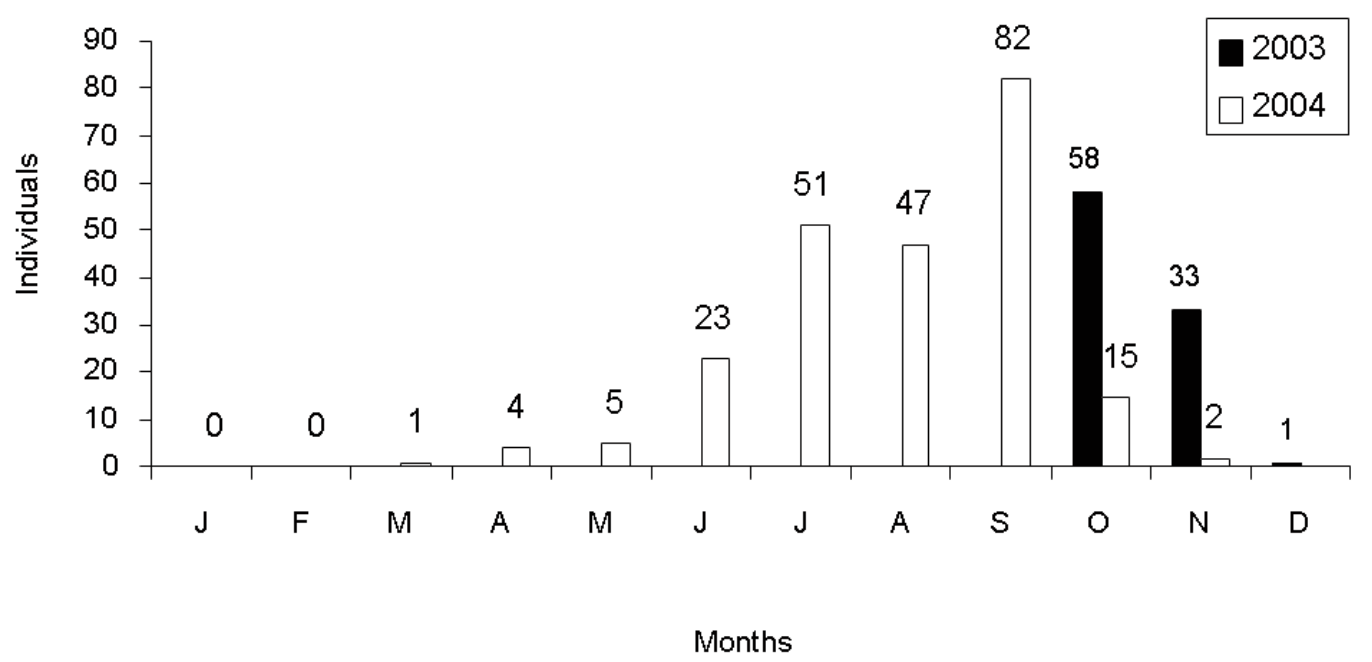

Fig. 1. Total abundance per month from October 2003 to November 2004 in the studied population of Kinosternon integrum. Solid bars indicate 2003 abundance. Open bars indicate 2004 abundance.

relative clutch mass (RCM) using Cuellar's (1984) formula:

\section{clutch weight/[female weight - clutch weight].}

We used typical linear regression analysis to test for significant relationships between body size and life history traits—-such as clutch size, egg size, and reproductive effort-and between pelvic width and egg width. In order to test for a pelvic restriction on egg size, we also used an analysis of covariance (ANCOVA) to examine and compare 2 relationships: pelvic aperture regressed on body size and egg width regressed on body size (PL as covariate). Variation between slopes indicates no pelvic restriction, whereas parallel slopes indicate pelvic restriction (Congdon and Gibbons 1987, Zar 1999). Statistical analyses were performed using the statistical software JMP, version 5.0.1 (SAS Institute, Inc. 2002).

\section{RESUlTS}

A total of 204 turtles were marked, and 118 individuals were recaptured (57.8\% of the total). Of these 204 turtles, 89 were females, 50 were males, and 65 were too small to be sexed and considered immature. Most of the individuals (184 or $90 \%$ ) were caught in the 50-m-diameter pond. Abundance per month was highest in September 2004, with 82 individuals captured, and lowest in January and February, with no individuals captured (Fig. 1). The abundance per month was related positively and significantly to temperature and rainfall together (slope for temperature $=-16.36, P=0.01$; slope for rainfall $\left.=5.64, P=0.02 ; r^{2}=0.76\right)$.

Estimated population size (adults and immatures) was 197 individuals (95\% CI 128-416). To support this estimate, we also tested the equal-catchability assumption for the marked individuals (Krebs 1996), finding a random capture probability per individual $\left(\chi^{2}{ }_{14}=16.43\right.$, $P=0.10)$. Population structure (Fig. 2) was $63 \%$ adults $(>90 \mathrm{~mm}$ CL), $0.5 \%$ hatchlings $(<3$ $\mathrm{mm}$ CL), 35\% immature individuals (30-90 mm CL), and $1 \%$ old adults (>17 mm CL). The sex ratio was skewed toward females, with 1 male (50) per 1.7 females (89). This result was significantly different from the 1:1 expected ratio $\left(\chi_{2}^{2}\right.$ $=10.94, P<0.001)$.

Sexual size dimorphism was evident; males were larger than females $\left(T^{2}, F_{5,106}=14.93\right.$, $\mathrm{P}<0.0001$; Table 1). Variables with the largest effects in the model were $\mathrm{CL}\left(\mathrm{CL}_{\text {males }}=\right.$ $156.3 \mathrm{~mm}, s=35.1 ; \mathrm{CL}_{\text {females }}=142.7 \mathrm{~mm}, s$ $=23.8)$ and $\mathrm{PL}\left(\mathrm{PL}_{\text {males }}=126.4 \mathrm{~mm}, s=\right.$ 26.0; $\left.\mathrm{PL}_{\text {females }}=119.5 \mathrm{~mm}, s=20.6\right)$. Body mass did not differ between males and females $\left(Z_{137}=1.67, P=0.09\right)$.

The breeding season extended from early summer (July) to mid-fall (October). Apparently, females experience a single reproductive event per year. The smallest female with oviductal eggs was $122 \mathrm{~mm}$ CL, and the largest was 153 


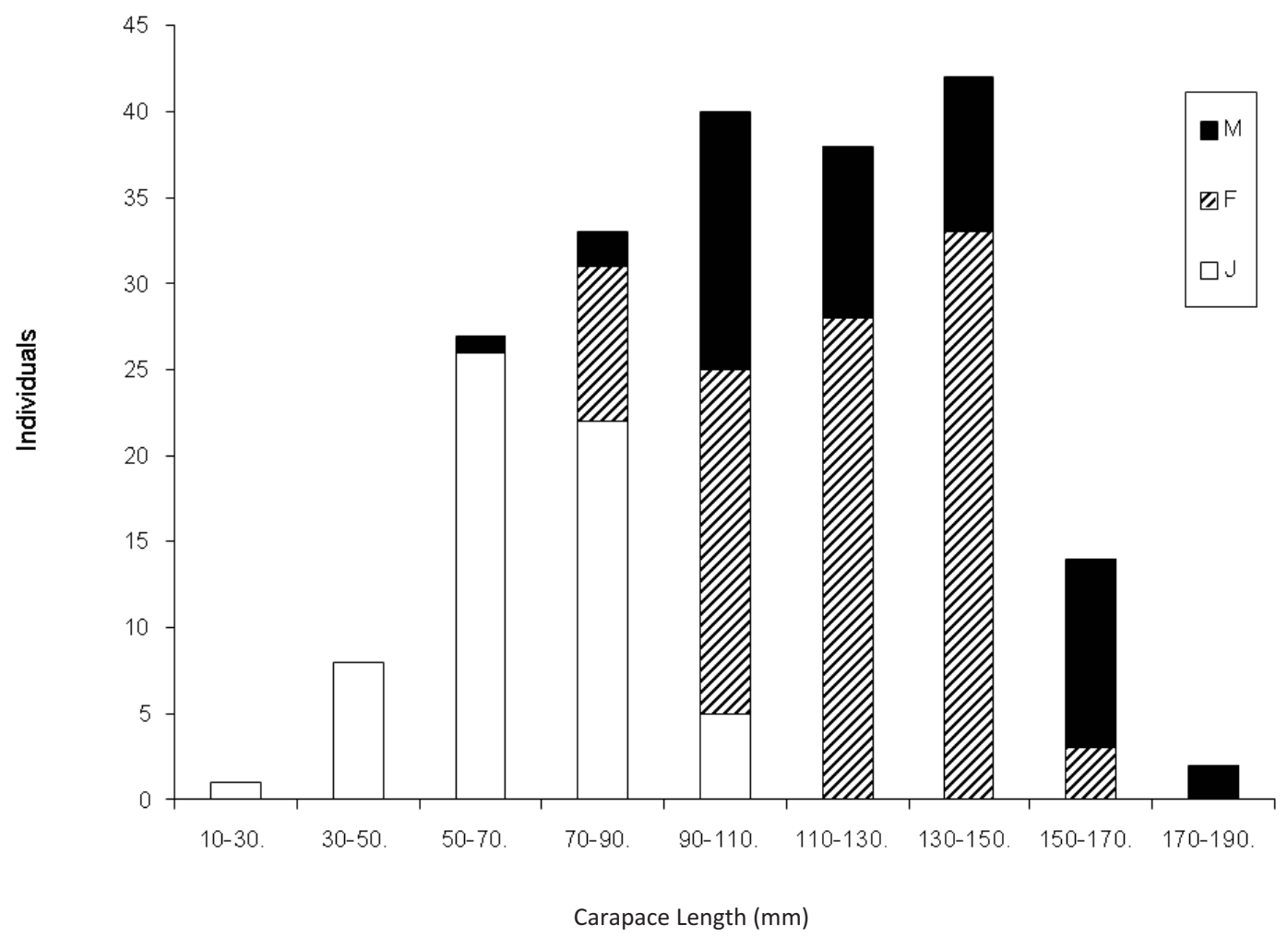

Fig. 2. Population structure by body size (carapace length) from October 2003 to November 2004 in the studied population of Kinosternon integrum. M represents males (solid bars), F represents females (dashed bars), and J represents immatures (open bars).

mm CL. Mean clutch size was 4 eggs $(s=1.77$, range $1-8, n=20)$. Of the 46 females collected during the breeding seasons (both 2003 and $2004)$, only $20(43.47 \%)$ had eggs in their oviducts. Mean egg length was $30.43 \mathrm{~mm}(s$ $=2.24$, range $23.92-35.96, n=78)$, mean egg width was $16.35 \mathrm{~mm}(s=1.01$, range $12.99-18.30, n=75$ ), and mean egg mass was $5.14 \mathrm{~g}(s=0.60$, range $3.41-6.57, n=57)$.

We found a positive relationship between clutch size (CS) and maternal body size using both CL and PL measurements (CS $=-10.38$ $+0.90 \mathrm{CL}, r^{2}=0.58, P=0.0003$; $\mathrm{CS}=$ $-13.64+1.32$ PL, $r^{2}=0.63, P=0.0001$; Fig. 3). Clutch size showed no relationship to egg width $\left(r^{2}=0.06, P=0.29\right)$ or egg mass $\left(r^{2}=\right.$ $0.11, P=0.16)$. However, there was a significant negative relationship between egg length and clutch size (egg length $=33.95-9.80 \mathrm{CS}$, $\left.r^{2}=0.66, P=0.0001\right)$, suggesting a tendency for smaller eggs as clutch size increases (Fig. 4). Reproductive effort, measured as RCM, was calculated only in the 16 females whose entire clutch was obtained. Average RCM was $0.043(s=0.017$, range 0.017-0.071, $n=16)$; thus, females on average invested $4.43 \%$ of their body mass in the production of eggs. RCM was not related to body size measured either as CL $\left(r^{2}=0.005, P=0.77\right)$, PL $\left(r^{2}=0.001, P\right.$ $=0.88)$, or CS $\left(r^{2}=0.21, P=0.07\right)$.

Females of $K$. integrum in Tonatico did not show evidence of a pelvic constraint on egg size. The pelvic aperture (PA) was positively correlated with body size (PL) $(\mathrm{PA}=-2.4+$ $\left.0.145 \mathrm{PL}, r^{2}=0.62, P<0.0001\right)$, in contrast to egg width, which was not correlated with body size $(\mathrm{PL})\left(r^{2}=0.13, P=0.11\right)$. Furthermore, the estimated variation in egg width was less $\left(s^{2}=0.85\right)$ than the variation in pelvic aperture $\left(s^{2}=1.77\right)$. Obviously then, the pelvic aperture was not related to egg width $\left(r^{2}=\right.$ $0.12, P=0.12$ ). The ANCOVA showed that the 2 slopes, PA vs. PL and EW vs. PL (Fig. 5), were significantly different $\left(F_{1,38}=156.03, P\right.$ 
TABLE 1. Summary of morphological traits measured for males and females of Kinosternon integrum at Tonatico, Estado de México.

\begin{tabular}{|c|c|c|}
\hline Trait & Males & Females \\
\hline \multicolumn{3}{|l|}{ Carapace length $(\mathrm{mm})$} \\
\hline Sample size & 50 & 89 \\
\hline Mean & 156.3 & 142.7 \\
\hline Standard deviation & 35.1 & 23.8 \\
\hline Range & $82.0-223.0$ & $90.0-195.0$ \\
\hline \multicolumn{3}{|l|}{ Carapace width (mm) } \\
\hline Sample size & 50 & 89 \\
\hline Mean & 126.9 & 122.6 \\
\hline Standard deviation & 29.0 & 22.7 \\
\hline Range & $70.0-183.0$ & $75.0-163.0$ \\
\hline \multicolumn{3}{|l|}{ Plastron length (mm) } \\
\hline Sample size & 50 & 89 \\
\hline Mean & 126.4 & 119.5 \\
\hline Standard deviation & 26.0 & 20.6 \\
\hline Range & $66.0-172.0$ & $73.0-155.0$ \\
\hline \multicolumn{3}{|l|}{ Plastron width (mm) } \\
\hline Sample size & 50 & 88 \\
\hline Mean & 67.3 & 66.9 \\
\hline Standard deviation & 13.3 & 12.1 \\
\hline Range & $35.0-95.0$ & $40.0-90.0$ \\
\hline \multicolumn{3}{|l|}{ Carapace height (mm) } \\
\hline Sample size & 37 & 76 \\
\hline Mean & 50.9 & 47.5 \\
\hline Standard deviation & 11.1 & 9.8 \\
\hline Range & $32.9-76.0$ & $21.8-69.1$ \\
\hline \multicolumn{3}{|l|}{ Body mass (g) } \\
\hline Sample size & 50 & 89 \\
\hline Mean & 336.83 & 281.35 \\
\hline Standard deviation & 190.42 & 143.60 \\
\hline Range & $49.82-774.08$ & $60.65-654.20$ \\
\hline
\end{tabular}

$<0.0001)$. According to Congdon and Gibbons (1987), this nonparallel pattern of slopes demonstrates a lack of pelvic constraint upon egg size.

\section{Discussion}

The sex ratio was significantly biased to $K$. integrum females $(1: 1.7)$ and differed from the theoretical 1:1 expected (Seger and Stubblefield 2002). We captured turtles systematically with a seine and consider this observed sex ratio to be representative of the studied population. Male-biased sex ratios have been found for Sternotherus odoratus (Edmonds and Brooks 1996, Smith and Iverson 2002) and femalebiased sex ratios for K. subrubrum (Gibbons 1983), K. herrerai (Carr and Mast 1988), and K. flavescens (Iverson 1991a). Sex of turtles is determined by incubation temperature or by sexual chromosomes (Ewert and Nelson 1991). In kinosternids, both patterns are present (Ernst et al. 1994, Pough et al. 2001); Kinosternon, Sternotherus, and Claudius species have specific temperatures for sex determination, whereas sex of Staurotypus species is determined by sexual chromosomes (Pough et al. 2001). Typically, when sex is determined by temperature, females are produced at extreme temperatures and males at intermediate ones. Therefore, female-biased sex ratios could be explained by the environmental temperature through time. However, Gibbons (1990) also mentioned that the main factors skewing sex ratios are local demographic processes, such as differential migration and immigration and differential ages of maturity between sexes. A combination of these factors could explain the biased sex ratio in $K$. integrum from Tonatico. Further research is needed on factors influencing observed sex ratio.

The population was composed primarily of immature and adult individuals; there were few old individuals and hatchlings were scarce. This pattern coincides with the survivorship curve reported for turtles by Iverson (1991b), in which immature organisms have the lowest probability of surviving and adults the highest. Nonetheless, Gibbs and Amato (2000) defined healthy (turtle) populations as structured mainly by young and prereproductive individuals and just a few adults. The population structure of $K$. integrum in Tonatico differed from this pattern. Abundance per month was highly correlated with temperature and rainfall, as is the case for other kinosternid species distributed in the northern hemisphere (Iverson 1986, 1989, 1991a, Frazer 1991). Morales-Verdeja and Vogt (1997) suggested that in the tropics, rainfall is the primary factor affecting turtle activity. Our findings agree with this suggestion, because in the Tonatico population turtles were more abundant during the rainy season (summer to mid-fall) and most of them estivate during the dry season.

We report the first population size estimate for $K$. integrum. Most individuals were found in a single small and shallow pond $(50 \mathrm{~m}$ in diameter). This higher abundance may be related to the proximity of a running water system, in contrast with the other ponds surveyed $(200,20,10,8$, and $5 \mathrm{~m}$ in diameter) that are isolated from streams or rivers. The high concentration of individuals in the 50-m 

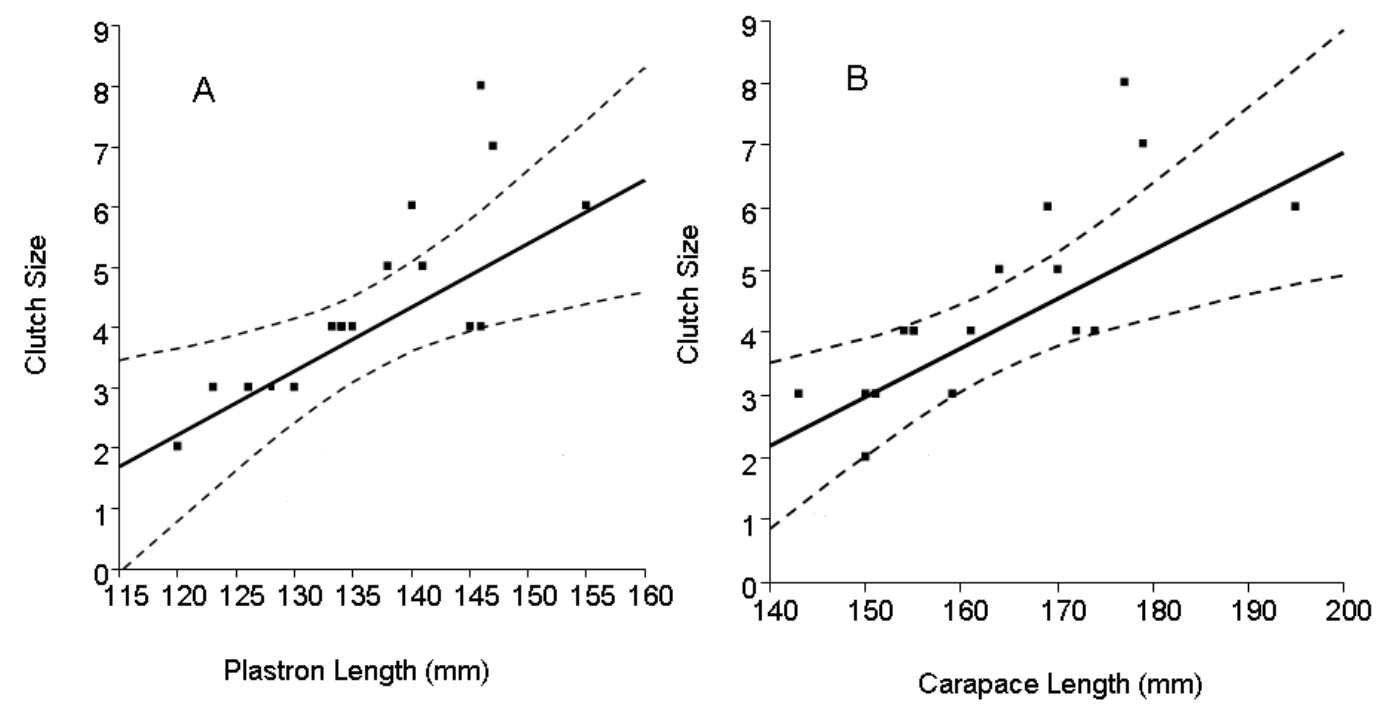

Fig. 3. Relationships between clutch size and maternal body size measured as (A) plastron length and (B) carapace length for the studied population of Kinosternon integrum. Dashed lines represent 95\% confidence intervals.

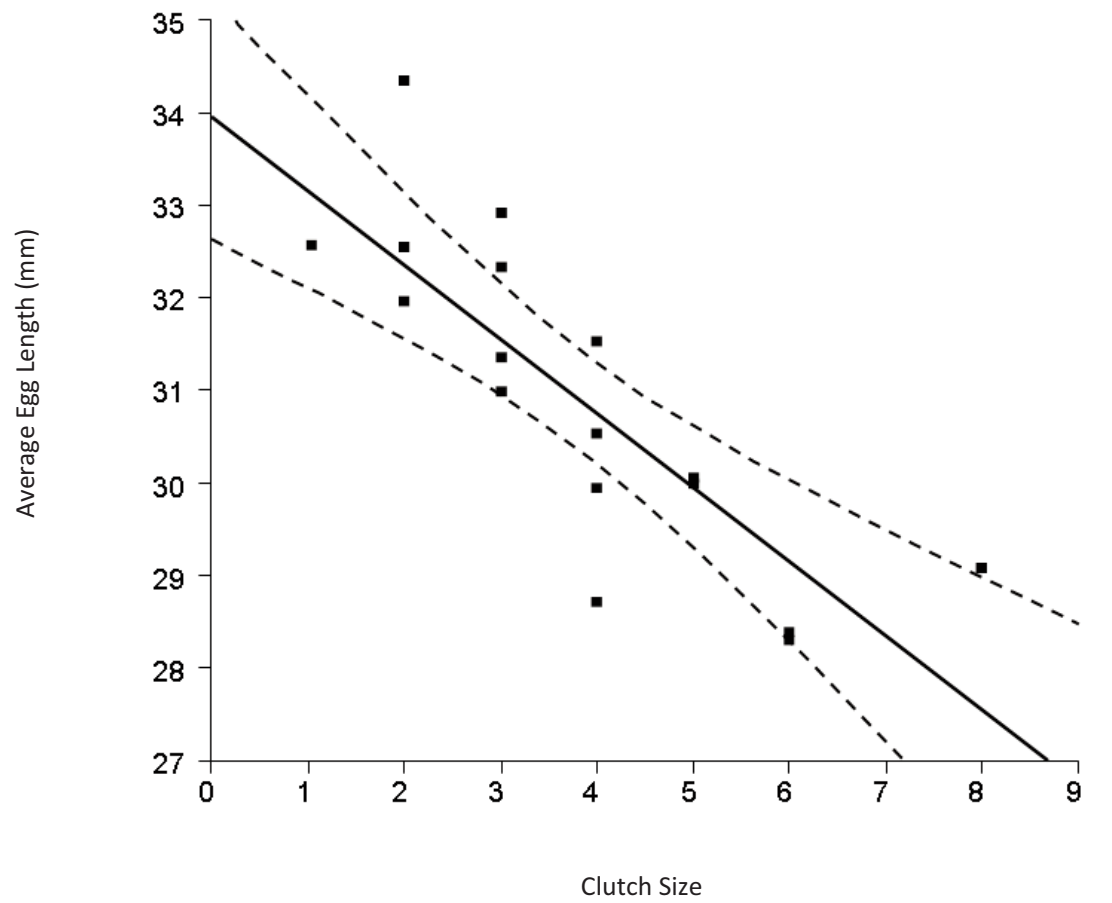

Fig. 4. Relationship between average egg length $(\mathrm{mm})$ and clutch size in the studied population of Kinosternon integrum. Dashed lines represent $95 \%$ confidence intervals. 


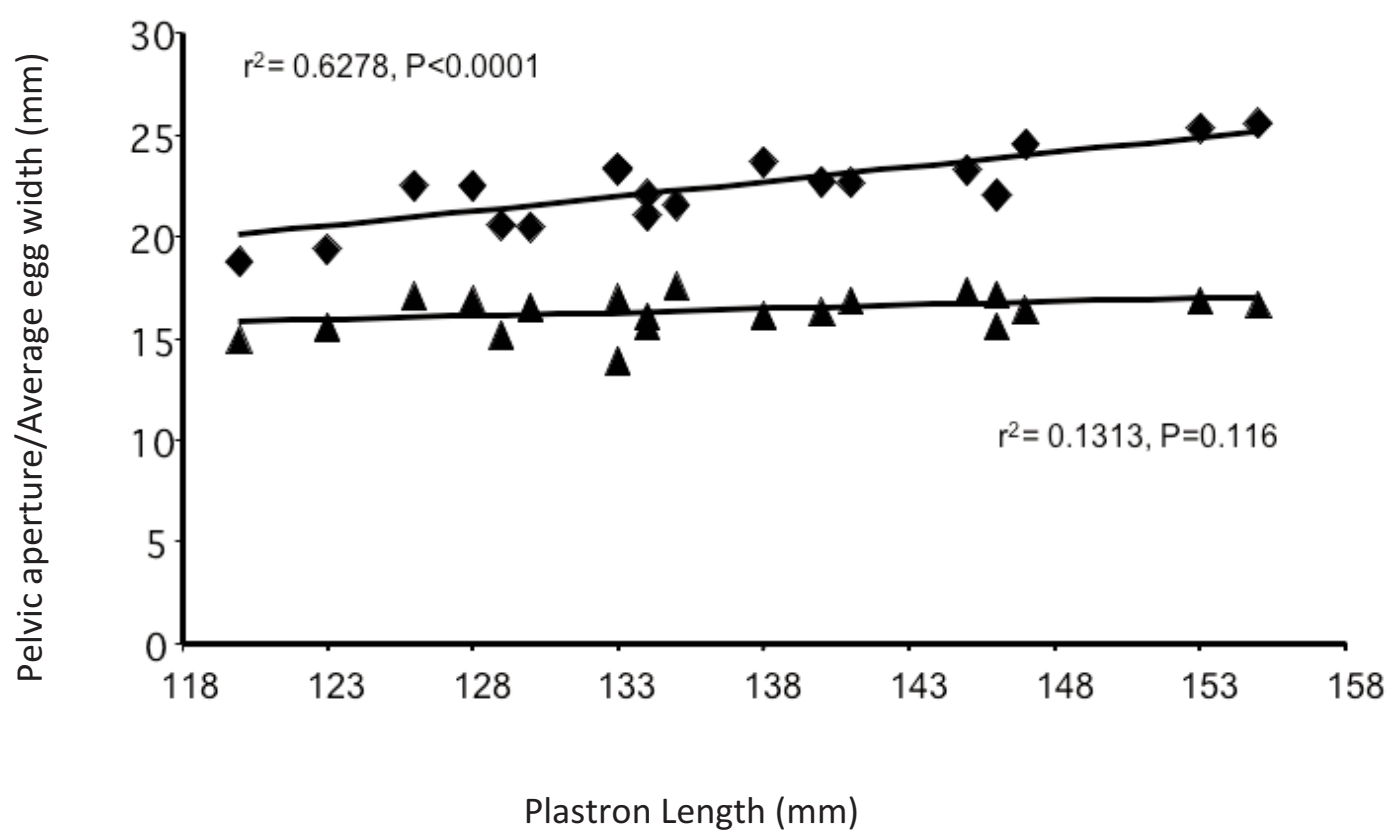

Fig. 5. Comparison of slopes for the relationships between plastron length and size of pelvic aperture (diamonds) and between plastron length and mean egg width (triangles) for the studied population of Kinosternon integrum. The $r^{2}$ coefficient and $P$ value for each relationship are presented.

pond could also be explained by the high productivity of this pond via the constant input of organic matter from cattle. Seasonal aquatic habitats have been considered highly productive (Lampert and Sommer 1997). The presence of second- and third-year turtles (nonreproductive individuals) suggests that the habitat also contains suitable nesting sites. Morales-Verdeja and Vogt (1997) found in K. leucostomum a similar abundance and distribution pattern.

Kinosternon integrum is one of the largest species of the genus, and in fact, we recorded in Tonatico the largest male in terms of carapace length $(223 \mathrm{~mm})$ observed for the species (Macip-Ríos and Casas-Andreu 2006). Sexual size dimorphism is common in this group of turtles (Carr and Mast 1988, Iverson 1989, Iverson et al. 1991). Our results indicate that males are larger than females, and this pattern of sexual size dimorphism in kinosternids has been explained as a result of males' territorial behavior: the bigger the male, the better the phenotype for competing for territories and females (Wilbur and Morin 1988). Other kinosternids like $K$. scorpioides (Pritchard and Trebbau 1984), K. oaxacae (Iverson 1986), K. herrerai (Carr and Mast 1988), K. creaseri (Iverson 1988), and K. alamosae (Iverson 1989) show similar sexual dimorphism patterns with larger males.

The reproductive season of $K$. integrum in Tonatico (July-October) was similar to that reported for other freshwater turtles in North America, like Chrysemys picta (Iverson and Smith 1993), Apalone ferox (Iverson and Moller 1997), and Chelydra serpentina (Iverson et al. 1997). The breeding season was also related to weather because these turtles need water for courtship and mating. Iverson (1999) reported a breeding season for $\mathrm{K}$. integrum (data from several populations) from May to September; our findings extend that period by one month. The smallest female found with eggs in Tonatico was $122 \mathrm{~mm}$ in plastron length, almost the same size that Iverson (1999) reported previously (123 mm) in the upper Balsas River basin in Puebla. Average clutch size in the Tonatico population (4 eggs) was smaller than the average clutch size found by Iverson (1999; 5.8 eggs). However, we estimated clutch size by counting oviductal eggs on X-ray plates, which is more accurate than counting corpora lutea (Congdon and Gibbons 1990), as Iverson (1999) did. 
As in other species of freshwater turtles, a significant positive relationship between body size and clutch size was observed in $K$. integrum at Tonatico (Congdon and Gibbons 1983, Iverson and Smith 1993, Iverson et al. 1997, Boot 1998). This pattern is more or less generalized in turtles (Congdon and Gibbons 1983, Iverson and Smith 1993, Iverson et al. 1997), as well as in other ectotherms such as lizards (Ballinger 1983) and snakes (Bronikowski and Arnold 1999). In addition, our results agree with a basic life history pattern, that suggests a trade-off between egg size and clutch size (Roff 2002). This pattern has been reported in other freshwater turtles (Congdon and Gibbons 1983, Iverson and Smith 1993, Iverson et al. 1997), in Iverson's (1999) combined data for K. integrum, as well as in other vertebrates like lizards (Sorci and Clobert 1999, Warne and Charnov 2008), snakes (Bronikowski and Arnold 1999), and mammals (Charnov and Ernest 2006).

We found that only $43.47 \%$ of females had oviductal eggs. These findings are consistent with findings for other species like $K$. subrubrum (Frazer 1991) and K. flavescens (Iverson 1991), which had an average of $50 \%$ gravid females per population. This trend is also common in organisms considered "bet hedgers" (Cunnington and Brooks 1996, Roff 2002, Fox and Rauter 2003) and grants them breeding opportunity every 2 or 3 seasons (Frazer 1991, Iverson 1991a), giving them the advantage of investing more energy in survival and growth than in reproduction. Mean reproductive effort is the lowest recorded for kinosternids (Table 2 ), but further intra- and interspecific comparisons of this trait and its relationships with body size and with other life history variables are needed in order to understand this result.

The lack of a pelvic constraint on egg size in the Tonatico population allows the smallest reproductive individuals to produce eggs of the same width as those of larger individuals. If there were a selective pressure for increasing egg size, this could be attained by increases in egg length, which according to our results shows a higher variation. In contrast, there is evidence of a pelvic constraint on egg size in other freshwater turtles (Congdon and Gibbons 1987). According to theoretical predictions (Congdon and Gibbons 1987), larger turtle species should not show a pelvic constraint, whereas smaller species should. Further 
research is needed to clarify what kinosternids (considered small species) can tell us about this issue.

\section{ACKNOWLEDGMENTS}

We thank Gabriel Barrios, Victor Sustaita, Cinthya Mendoza, and Ricardo Mariño for their collaboration with the fieldwork. Also, Fausto R. Mendez and Xavier Chiappa made interesting comments at the beginning of the study. CONACyT and DGEP (UNAM) supported RMR's graduate education during the study. We also thank Elizabeth Hassell for making an excellent English improvement to the submitted manuscript. Two anonymous reviewers made pertinent comments to this paper.

\section{Literature Cited}

Aguirre-León, G., And O. Aquino-Cruz. 2004. Hábitos alimentarios de Kinosternon herrerai Stejneger 1925 (Testudines: Kinosternidae) en el Centro de Veracruz, México. Acta Zoológica Mexicana (n.s.) 20:83-98.

Ballinger, R.E. 1983. Life history variations. Pages 241-260 in R.B. Huey, E.R. Pianka, and T.W. Schoener, editors, Lizard ecology: studies of a model organism. Harvard University Press, Cambridge, MA.

Berry, J.F., M.E. Seidel, AND J.B. Iverson. 1997. A new species of mud turtle (Genus Kinosternon) from Jalisco and Colima, México, with notes on its natural history. Chelonian Conservation and Biology 2: 329-337.

Bоотн, D.T. 1998. Egg size, and reproductive effort of the Australian broad-shelled river turtle, Chelodina expansa. Journal of Herpetology 32:592-596.

Bronikowski, A.M., And S.J. Arnold. 1999. The evolutionary ecology of life history variation in the garter snake Thamnophis elegans. Ecology 80:2314-2325.

CARR, J.L., AND R.B. Mast. 1988. Natural history observations of Kinosternon herrerai (Testudines: Kinosternidae). Trianea 1:87-97.

Charnov, E.L., And S.K.M. ERnEst. 2006. The offspringsize/clutch-size trade-off in mammals. American Naturalist 167:578-582.

Congdon, J.D., And J.W. GibBons. 1983. Relationships of reproductive characteristics to body size in Pseudemys scripta. Herpetologica 39:147-151.

1987. Morphological constraint on egg size: a challenge to optimal egg size theory? Proceedings of the Natural Academy of Sciences, USA 84: 4145-4147.

1990. The evolution of turtle life histories. Pages 45-54 in J.W. Gibbons, editor, Life history and evolution of the slider turtle. Smithsonian Institution Press, Washington, DC.

Cuellar, O. 1984. Reproduction in a parthenogenetic lizard: with a discussion of optimal clutch size and a critique of the clutch weight / body weight ratio. American Midland Naturalist 111:242-258.

Cunington, D.C., And R.J. Brooks. 1996. Bet-hedging theory and eigenelasticity: a comparison of the life histories of loggerhead sea turtles (Caretta caretta) and snapping turtles (Chelydra serpentina). Canadian Journal of Zoology 74:291-296.

Edmonds, J.H., And R.J. BRooks. 1996. Demography, sex ratio, and sexual size dimorphism in a northern population of common musk turtles (Sternotherus odoratus). Canadian Journal of Zoology 74:918-925.

Ernst, C.H., J.E. Lovich, And R.W. Barbour. 1994. Turtles of the United States and Canada. Smithsonian Institution Press, Washington, DC.

Etchberger, C.R., And L.M. Ehrhart. 1987. The reproductive biology of the female loggerhead musk turtle, Sternotherus minor minor, from the southern part of its range in central Florida. Herpetologica 43:66-73.

EwErT, M.A., AND J.M. LEgLER. 1978. Hormonal induction of oviposition in turtles. Herpetologica 34: 314-318.

Ewert, M.A., AND C.E. NELSON. 1991. Sex determination in turtles: diverse patterns and some possible adaptive values. Copeia 1991:50-69.

FERner, J. 1979. A review of marking techniques for amphibians and reptiles. Herpetological Circular No. 9, Society for the Study of Amphibians and Reptiles [www.ssarherps.org].

Fox, C.W., AND C.M. Rauter. 2003. Bet-hedging and the evolution of multiple mating. Evolutionary Ecology Research 5:273-286.

Frazer, N.B. 1991. Life history and demography of the common mud turtle Kinosternon subrubrum in South Carolina, USA. Ecology 72:2218-2232

GibBons, J.W. 1983. Reproductive characteristics and ecology of the mud turtle, Kinosternon subrubrum (Lacepede). Herpetologica 39:254-271.

1990. Sex ratios and their significance among turtle populations. Pages 171-182 in J.W. Gibbons, editor, Life history and ecology of the slider turtle. Smithsonian Institution Press, Washington, DC.

GibBs, J.P., and G.D. Amato. 2000. Genetics and demography in turtle conservation. Pages 207-217 in M.W. Klemens, editor, Turtle conservation. Smithsonian Institution Press, Washington, DC.

HuLSE, A.C. 1982. Reproduction and population structure in the turtle, Kinosternon sonoriense. Southwestern Naturalist 27:447-456.

INEGI. 2002. Anuario Estadístico del Estado de México. Gobierno del Estado de México-INEGI. México.

IVERSON, J.B. 1979. Reproduction and growth of the mud turtle, Kinosternon subrubrum, in Arkansas. Journal of Herpetology 13:105-111.

1986. Notes on the natural history of the Oaxaca mud turtle Kinosternon oaxacae. Journal of Herpetology 20:119-123.

1988. Distribution and status of Creaser's mud turtle, Kinosternon creaseri. Herpetological Journal 1:285-291.

1989. Natural history of the Alamos mud turtle, Kinosternon alamosae (Kinosternidae). Southwestern Naturalist 34:134-142.

1991a. Life history and demography of the yellow mud turtle, Kinosternon flavescens. Herpetologica 47: 373-395.

1991b. Patterns of survivorship in turtles (order Testudines). Canadian Journal of Zoology 69:385-391. 1997. Local and geographic variation in the reproductive biology of the snapping turtle (Chelydra serpentina). Herpetologica 53:96-117.

1999. Reproduction in the Mexican mud turtle Kinosternon integrum. Journal of Herpetology 33: 144-148. 
2002. Reproduction in female razorback musk turtles (Sternotherus carinatus: Kinosternidae). Southwestern Naturalist 47:215-224.

Iverson J.B., E.L Barthelmess, G.R. Smith, and C.E. DeRivera. 1991. Growth and reproduction in the mud turtle Kinosternon hirtipes in Chihuahua, México. Journal of Herpetology 25:64-72.

Iverson, J.B., H. Higgins, A. Siruknik, AND C. Griffiths. 1997. Local and geographic variation in the reproductive biology of the snapping turtle (Chelydra serpentina). Herpetologica 53:97-117.

Iverson, J.B., AND P.E. Moler. 1997. The female reproductive cycle of the Florida softshell turtle (Apalone ferox). Journal of Herpetology 31:399-409.

IVERSON J.B., AND G.R. SMITH. 1993. Reproductive ecology of the painted turtle (Chrysemys picta) in the Nebraska Sandhills and across its range. Copeia 1993:1-21.

Iverson, J.B., C.A. Young, AND J.F. Berry. 1998. Kinosternon integrum LeConte. Catalogue of the American Amphibians and Reptiles. 652:1-6.

Lampert, W., and U. Sommer. 1997. Limnoecology. The ecology of lakes and streams. Oxford University Press, New York.

Liner, E.A., AND G. CASAS-ANDREu. 2008. Standard Spanish, English and scientific names of the amphibians and reptiles of Mexico. 2nd edition. Herpetological Circular No. 38, Society for the Study of Amphibians and Reptiles [www.ssarherps.org].

Krebs, C.J. 1996. Ecological methodology. 2nd edition. Addison Wesley Longman, Menlo Park, CA.

Krebs, C.J., And J. Brzustowski. 1998. Kreb/WIN (Ecological Methodology), version 0.94. Available from: $\mathrm{ftp} / / /$ gause.biology.ualberta.ca/puv/jbrzusto/krebs

Macip-Ríos, R., and G. CASAS-ANDREu. 2006. Size. Kinosternon integrum (Mexican mud turtle). Herpetological Review 37:79.

MitcheLL, J.C. 1985. Female reproductive cycle and life history attributes in a Virginia population of stinkpot turtles, Sternotherus odoratus. Copeia 1985:941-949.

. 1988. Population ecology and life histories of the freshwater turtles Chrysemys picta and Sternotherus odoratus in an urban lake. Herpetological Monographs 2:40-61

MoLL, D. 1990. Population sizes and foraging ecology in a tropical freshwater stream turtle community. Journal of Herpetology 24:48-53.
Morales-Verdeja, S.A., And R.C. Vogt. 1997. Terrestrial movements in relation to aestivation and the annual reproductive cycle of Kinosternon leucostomum. Copeia 1997:123-130.

Pough, H.F., R.M. Andrews, J.E. Cadle, M.L. Crump, A.H. SAVITZKY, AND K.D. Wells. 2001. Herpetology. 2nd edition. Prentice Hall, Upper Saddle River, $\mathrm{NJ}$.

Pritchard, P.C., and P. Trebbau. 1984. The turtles of Venezuela. Society for the Study of Amphibians and Reptiles [www.ssarherps.org].

RANCHER, A.C. 2002. Methods of multivariate analysis. 2nd edition. Wiley-Interscience, New York.

RofF, D.A. 2002. Life history evolution. Sinauer, Sunderland, MA.

SAS Institute, Inc. 2002. JMP. Statistical Discovery Software, Version 5.0.1. Cary, NC.

Seger, J., and W. Stubblefield. 2002. Models of sex ratio evolution. Pages 2-25 in I.C.W. Hardy, editor, Sex ratios: concepts and research methods. Cambridge University Press, Cambridge, MA.

Smith, G.R., AND J.B. Iverson. 2002. Sex ratio in common musk turtles (Sternotherus odoratus) in a north-central Indiana lake: a long-term study. American Midland Naturalist 148:185-189.

Sorci, G., and J. Clobert. 1999. Natural selection on hatchling size and mass in two environments in the common lizard (Lacerta vivipara). Evolutionary Ecology Research 1:303-316.

Warne, R.W., and E.L. Charnov. 2008. Reproductive allometry and the size-number trade-off for lizards. American Naturalist 172(3):E80-E98.

Wilbur, H.M., AND P.J. Morin. 1988. Life history evolution in turtles. Pages 396-447 in C. Gans and R. Huey, editors, Biology of the Reptilia. Volume 16, Ecology B: Defense and Life History. Alan R. Liss, New York.

WiLSON, K., AND I.C. HARDY. 2002. Statistical analysis of sex ratios: an introduction. Pages 48-92 in I.C. Hardy, editor, Sex ratios: concepts and research methods. Cambridge University Press, Cambridge, MA.

ZAR, J.H. 1999. Biostatistical analysis. 4th edition. Prentice Hall, Upper Saddle River, NJ.

Received 11 September 2008 Accepted 28 May 2009 